Vol. 1 No. 1 September 2021, e-ISSN : 2807-8667| p-ISSN : 2807-8837

\title{
PENERAPAN GENRE BASED APPROACH (GBA) DALAM PEMBELAJARAN BAHASA INGGRIS SMPN 1 PANIMBANG
}

\author{
DWI ESTRINI \\ SMPN 1 Panimbang \\ e-mail: dwiestrini@gmail.com
}

\begin{abstract}
ABSTRAK
Bahasa Inggris sebagai sebuah keterampilan harus dipelajari melalui tahapan yang jelas antara pemodalan, pemodelan dan latihan secara bertahap. Diperlukan suatu model pembelajaran Bahasa Inggris yang mampu memberikan pengalaman belajar tersebut. Tulisan ini betujuan untuk merefleksikan pembelajaran Bahasa Inggris dalam tema Comparing Things and Animals dengan menerapkan Genre Based Approach dengan Model Teaching Learning Cycles (TLC). Penelitian dilaksanakan di Kelas VIII F SMP 1 Panimbang, Banten dengan melibatkan 32 orang peserta didik. Data dikumpulkan dengan berbagai teknik yaitu observasi dan refleksi, penugasan dan tes, focus group discussion (FGD), dan dokumentasi. Data tersebut kemudian dianalisis dengan teknik analisis deskriptif. Dari analisis data dan refleksi pembelajaran dapat disimpulkan bahwa (1) dengan penerapan GBA dengan Model TLC peserta didik memiliki pengalaman secara bertahap dari pemberian modal pengetahuan (concept building), model, dan serangkaian latihan baik secara berkelompok maupun individu; (2) penerapan GBA juga mampu mengakomodasi unsur 4C dalam Keterampilan Pembelajaran Abad 21; (3) terjadi peningkatan tingkat ketuntasan belajar dari 39,72\% dengan rata-rata 60,28 sebelum pembelajaran menjadi $87,19 \%$ dengan rata-rata 81,67 sesudah pembelajaran; (4) kedua observer memberikan penilaian postif terhadap proses pembelajaran dengan penerapan GBA dengan Model TLC.
\end{abstract}

Kata Kunci: Bahasa Inggris, GBA, Model TLC, comparing things, animals

\section{PENDAHULUAN}

Pada era globalisasi dan revolusi industri, Bahasa Inggris diyakini memiliki peran yang sangat sentral dan merupakan kunci untuk "membuka dunia". Membekali generasi muda dengan kemampuan Bahasa Inggris yang memadai untuk menyongsong masa depan merupakan suatu tuntutan mutlak. Ironisnya, di tengah gencarnya tuntutan meningkatkan kualitas sumber daya manusia (SDM) melalui penguasaan Bahasa Inggris, pemerintah Indonesia justru memangkas jam mata pelajaran Bahasa Inggris pada Kurikulum 2013. Bahkan Bahasa Inggris sebagai muatan lokal di sekolah dasar dihilangkan, padahal alasan pemberian Bahasa Inggris SD sebagai muatan lokal dalam kurikulum sebelumnya adalah untuk memperbanyak input dan memperhatikan keunggulan usia anak dalam belajar bahasa (Depdiknas, 2004).

Di Sekolah Menengah Pertama (SMP), Bahasa Inggris diajarkan dua kali seminggu dengan durasi dua jam pelajaran (80 menit). Dengan penghapusan mulok Bahasa Inggris di SD, mata pelajaran Bahasa Inggris di SMP merupakan mata pelajaran baru dan dianggap pelajaran sulit oleh sebagian besar peserta didik. Hal ini menimbulkan berbagai kendala dalam pembelajaran Bahasa Inggris. Akumulasi dari kendala tersebut tampak pada hasil pembelajaran Bahasa Inggris secara umum, yaitu setelah enam tahun belajar Bahasa Inggris wajib di sekolah menengah, pembelajaran ini belum menunjukan hasil yang menggembirakan. Dengan kata lain, belum seimbang antara usaha yang dikeluarkan dengan hasil yang dicapai. Tentu ada yang salah dalam pembelajaran Bahasa Inggris sebagai bahasa asing di Indonesia.

Salah satu usaha pemerintah dalam rangka memutus mata rantai kegagalan ini adalah dengan mengadakan Kegiatan Peningkatan Kompetensi Pembelajaran (PKP). Kegiatan ini yang bertujuan untuk meningkatkan kompetensi peserta didik melalui pembinaan guru dalam merencanakan, melaksanakan sampai dengan mengevaluasi pembelajaran yang berorientasi pada keterampilan berpikir tingkat tinggi (HOTS) dan berpusat pada peserta didik (SCL) (Ditjen GTK, 2019). 
Tulisan ini merupakan salah satu rangkaian pengembangan kompetensi guru Bahasa Inggris dalam merencanakan dan melaksanakan pembelajaran melalui kegiatan PKP yang dilaksanakan oleh Direktorat GTK melalui Dinas Pendidikan Kota Banten. Dari diskusi dengan teman sejawat, Kompetensi Dasar yang dikembangkan dan dimplementasikan dalam kegiatan ini adalah KD 3.9 (Pengetahuan) yaitu peserta didik mampu menerapkan fungsi sosial, struktur teks, dan unsur kebahasaan teks interaksi transaksional lisan dan tulis yang melibatkan tindakan memberi dan meminta informasi terkait perbandingan jumlah dan sifat orang, binatang, benda, sesuai dengan konteks penggunaannya dan KD 4.9 (Keterampilan), yaitu mampu menyusun teks interaksi transaksional lisan dan tulis sangat pendek dan sederhana yang melibatkan tindakan memberi dan meminta informasi terkait perbandingan jumlah dan sifat orang, binatang, benda, dengan memperhatikan fungsi sosial, struktur teks, dan unsur kebahasaan yang benar dan sesuai konteks (Kemendikbud, 2017). Pemilihan KD didasarkan pada urutan materi yang berlangsung pada saat implementasi (best practices) kegiatan PKP supaya tidak mengganggu materi kelas.

Pencapaian kedua KD tersebut dikemas dengan penerapan Genre Based Approach (GBA) dengan menggunakan Teaching Learning Cycle (TLC) Model, suatu model pembelajaran yang melekat pada pembelajaran berbasis teks. Sebagaimana diketahui bahwa sejak penerapan kurikulum berbasis komptensi tahun 2004 berlanjut dalam KTSP 2006, model pendekatan penyusunan kurikulum dan silabus menggunakan pembelajaran berbasis teks (Sujana, Nuryanti, \& Narasintawati, 2010; Cahyono, 2011). Dalam K13, penerapan TLC sebagai sebuah pembelajaran berorientasi pada peserta didik masih tetap direkomendasikan (Kemendikbud, 2017).

Dasar pertimbangan pemilihan GBA dengn TLC Model sebagai solusi dalam penelitian ini adalah Bahasa Inggris sebagai sebuah keterampilan perlu dilakukan pembiasaan melalui serangkaian latihan yang dilakukan secara bertahap. Untuk bisa melakukan kegiatan latihan dengan baik, peserta didik harus memiliki bekal pengetahuan yang memadai. Sujana, Waluyo, Soepriyanti, \& Arifuddin (2019) menegaskan pentingnya Modal (bekal pengetahuan) untuk melakukan suatu kegiatan dan Modal ini bisa diperoleh melalui Model (Modelling). Dalam pembelajaran Bahasa Inggris, Modal ini dapat berupa pemberian konteks pada topik/tema/teks yang akan dibahas, kosakata terkait, unsur gramatika yang relevan, dan konteks penggunaan bahasa terkait. Unsur-unsur tersebut bisa diambil dari Model komunikasi. Dengan penerapan model pembelajaran TLC, pelibatan pemodalan, pemodelan, dan latihan secara berkelompok, dan latihan mandiri semua terpenuhi. Menurut Brindley (1989), TLC adalah suatu model pengajaran bahasa Inggris melalui langkah-langkah pengenalan model teks, analisa teks, latihan gap-info, pengayaan language focus, negosiasi teks dengan variasi kegiatan: klasikal, berpasangan, kelompok dan individual. Sintaks umum dari Model TLC meliputi (1) Building Knowledge of the Field (BKOF), Modelling of the Text (MOT), (3) Joint Construction of the Tect (JCOT), dan (4) Independent Construction of the Text (ICOT) dengan tujuan kegiatan masing- masing.

Langkah-langkah penerapan Model TLC di atas sejalan dengan pendekatan yang disarankan dalam K-13 yaitu Pendekatan Saintifikyang memiliki 5 langkah pembelajaran yang dikenal dengan 5M (mengamati, menanya, mengumpulkan data, mengasosiasi, dan mengkomunikasikan). Amalia \& Hariono (2015) yang melakukan studi tentang integrasi GBA ke dalam Pendekatan Saintifik menyimpulkan bahwa langkah-langkah pembelajaran dalam Pendekatan Saintifik telah tergambar dalam 4 langkah pembelajaran GBA. Dari penelitian yang dilakukan Douangmala \& Widyantoro (2017) dan Liang (2015), disimpulkan bahwa TLC sangat potensial dalam memaksimalkan proses belajar mengajar Bahasa Inggris. Sujana \& Puniawati (2020) juga menilai bahwa penerapan TLC Model merupakan model pembelajaran yang berbasis pada peserta didik yang langkah-langkah pembelajarannya sejalan dengan tuntutan unsur 4C (Creativity, Collaboration, Critical Thinking, \& Communication) dalam Keterampilan Pembelajaran Abad 21. 
Berdasarkan paparan di atas, kegiatan penelitian ini secara umum bertujuan untuk merefleksikan perencanaan, proses, dan hasil pembelajaran Bahasa Inggris dengan menerapkan Genre-Based Approach (GBA) dengan Model Teaching Learning Cycles (TLC) dalam Program Peningkatan Kompetensi Pembelajaran (PKP) Kota Banten Banten; dan secara khusus untuk meningkatkan kemampuan berbahasa Inggris peserta didik Kelas VIIIF SMPN 1 Panimbang dengan menerapkan Genre-Based Approach (GBA) dengan Model Teaching Learning Cycles (TLC) dalam topik teks interpersonal dan transaksional membandingkan benda, orang, dan binatang.

\section{METODE PENELITIAN}

Penelitian ini merupakan penelitian kualitatif dengan mengamati perencanaan, pelaksanaan, dan hasil pembelajaran Bahasa Inggris di SMPN 1 Panimbang, Banten. Kegiatan penelitian ini merupakan rangkaian dari kegiatan Peningkatan Kompetensi Pembelajaran (PKP) yang diselenggarakan oleh diselenggarakan oleh Direktorat Jenderal Guru dan Tenaga Kependidikan (GTK) Kementerian Pendidikan dan Kebudayaan, Jakarta. Penelitian ini dilaksanakan di SMP 1 Panimbang dengan melibatkan peserta didik kelas VIIIF yang seluruhnya berjumlah 32 orang dan diobservasi oleh guru Bahasa Inggri. Data dikumpulkan dengan berbagai teknik (triangulasi) yaitu (a) pengamatan untuk mengumpulkan data terkait dengan proses pembelajaran, (b) Focus Group Discussion (FGD) untuk merefleksikan kegiatan pembelajaran dengan pengamat, (c) tes dalam bentuk pre-test dan post test, untuk melihat perkembangan peserta didik, dan (d) dokument perangkat pembelajaran (RPP, materi pembelajaran, media, dan alat evaluasi). Data yang terkumpul kemudian dianalisis dengan teknik analisis deskriptif.

\section{HASIL DAN PEMBAHASAN}

\section{Pelaksanaan Pembelajaran}

Kegiatan pembelajaran dibagi atas 3 tahapan inti yaitu kegiatan awal, kegiatan inti dan kegiatan akhir. Pembelajaran diawali dengan kegiatan pendahuluan yaitu (a) orientasi, (b) Penguatan Pendidikan Karakter (PPK) dengan bersama-sama menyanyikan lagu perjuangan sesuai dengan perayaan Hari Pahlawan, (c) kegiatan apersepsi dengan memancing ingatan peserta didik dengan pertanyaan-pertanyaan seputar materi prasyarat, yaitu tentang adjective, descriptive adjective dan adjective of quantity; (d) pemberian motivasi dan penyampaian tujuan pembelajaran.

Pada saat kegiatan inti, pada tahap Building Knowledge of Field (BKOF), peserta didik sambil memperhatikan tayangan gambar, mereka menyimak kalimat-kalimat yang diucapkan guru. Peserta didik diminta untuk mengidentifikasi kata-kata terkait dengan penggunaan kata adjective, descriptive teks dan adjective of quantity. Peserta didik diminta untuk memperhatikan tayangan gambar yang disertai dengan kalimat-kalimat. Guru meminta peserta didik untuk mengidentifikasi kembali jenis kata yang terkait dengan topik pembelajaran.

Setelah menguasai konsep dalam kegiatan BKOF, peserta didik diberikan model model atau contoh (Modelling of the Text) berdasarkan modal (pemahaman konsep) yang diajarkan. Guru melibatkan peserta didik yang "fast learner" untuk memberikan model kepada teman-temannya. Bersama-sama mereka mulai belajar menggunakan modal (konsep) yang ada untuk membuat kalimat yang mengandung phrase descriptive adjective dan adjective of quantity. Setelah itu mereka, diperkenalkan dengan degrees of comparison yang sederhana, dari yang positive, comparative dan superlative. Peserta didik diajak mengamati tayangan gambar; 2 gambar yang sama untuk yang positive degree dan 3 gambar yang berbeda untuk yang comparative dan superlative degree.

Pada tahap Joint Construction, peserta didik dibagi atas 6 kelompok, dimana masingmasing kelompok terdiri dari 5 anggota. Setiap kelompok mendapatkan 1 lembar kerja (LK) serta beberapa paper strips. Setiap kelompok diminta untuk menuliskan kata atau frase yang tergolong descriptive adjective dan adjective of quantity pada setiap paper strip tersebut yang 
kemudian ditempelkan pada kolom yang sudah disediakan pada LK. Diberikan waktu lebih kurang 10 menit untuk kegiatan tersebut. Setelah itu, langsung dibahas dan kemudian dihitung dan ditentukan kelompok mana yang paling banyak jumlah jawaban benarnya.

\section{Hasil Penilaian dan Observasi}

Setelah penerapan Pendekatan Berbasis Genre (GBA) dengan model TLC, banyak gejala positif yang ditunjukkan oleh peserta didik. Dengan adanya tahap Building Knowledge, dimana peserta didik sudah diberikan modal untuk kemudian digunakan sebagai medel maka peserta didik lebih percaya diri untuk berperan lebih aktif dalam proses pembelajaran. Peserta didk menunjukkan semangat dan rasa senang dalam mengerjakan LK karena sudah didukung dengan modal yang cukup banyak.

Selain dari gejala tersebut di atas, gejala dari aspek kognitif juga terlihat dari peningkatan pencapaian kompetensi peserta didik. Pencapaian kompetensi peserta didik sebelum dan sesudah diterapkan pendekatan dan model pembelajaran ini menunjukkan perbedaan yang cukup signifikan. Rata-rata skor sebelum pembelajaran adalah 60,28 dengan rentangan skor 25 -90 dan ketuntasan baru mencapai 39,72\% menjadi 81,67 sesudah pembelajaran dengan rentangan skor 50

- 100 dan tingkat ketuntasan mencapai 87,19\%. Secara lengkap, hasil yang dicapai disajikan pada

Tabel 1 dan Gambar 4 berikut.

Tabel 1. Ketuntasan sebelum dan sesudah pembelajaran

\begin{tabular}{|l|l|l|l|l|l|}
\hline \multirow{2}{*}{ Rentang Skor } & \multirow{2}{*}{ Kategori } & \multicolumn{2}{|c|}{ Sebelum } & \multicolumn{2}{c|}{ Sesudah } \\
\cline { 3 - 6 } & & Frek (f) & $\%$ & Frek (f) & $\%$ \\
\hline$>75$ & Tuntas & 11 & 39,72 & 25 & 87,67 \\
\hline$<75$ & Tidak Tuntas & 21 & 60,28 & 7 & 12,33 \\
\hline \multicolumn{2}{r}{} & 32 & 100 & 32 & 100 \\
\hline \multicolumn{2}{r}{ Rentang Skor } & \multicolumn{2}{|c|}{$25-90$} & \multicolumn{2}{c|}{$50-100$} \\
\hline
\end{tabular}

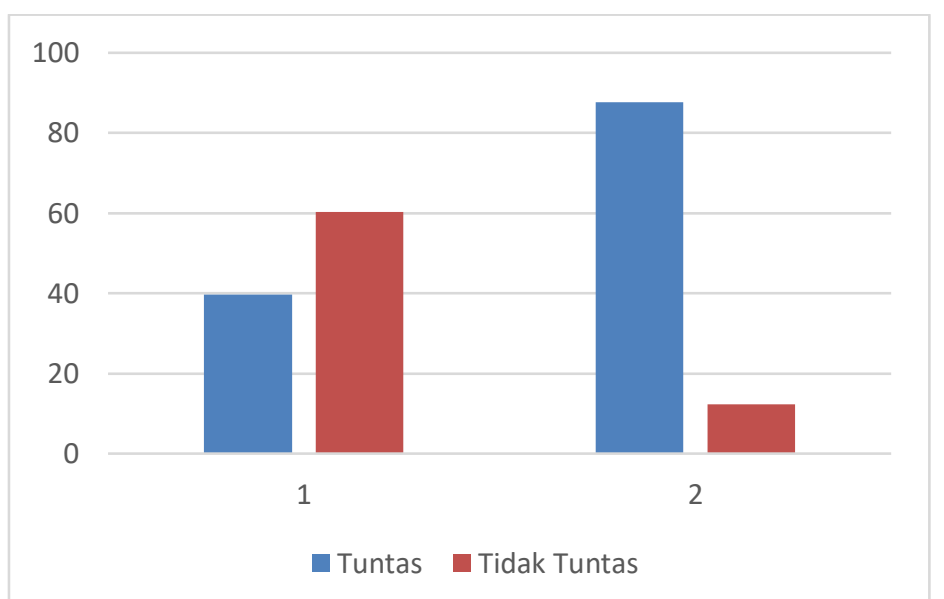

\section{Gambar 1. Ketuntasan sebelum dan ssuadah pembelajaran}

Hasil observasi dari guru Bahasa Inggris di sekolah menunjukkan respon positif terhadap pembelajaran. Secara lengkap hasil pengamatan pembelajaran dirangkum pada Tabel 2 berikut.

Dari hasil FGD, diperoleh hasil bahwa (1) Kegiatan pendahuluan dilaksanakan secara terstruktur dan tujuan pembelajaran disampaikan secara lisan dan tertulis; (2) Kegiatan Inti menunjukan kegiatan pembelajaran yang teroganisir dengan baik, baik dari segi penguasaan materi dan pengelolaan pembelajaran, pelibatan peserta didik, integrasi inovasi pembelajaran, penggunaan sumber belajar, dan penilaian. Satu catatan dari pengamat adalah pembiasaan penggunaan media LCD perlu ditingkatkan. Pengamat juga menilai positif pelibatan siswa dalam membuat rangkuman dan kegiatan refleksi pembelajaran dan materi sebagai kegiatan akhir. 
Secara keseluruhan, kegiatan FGD menyimpulkan bahwa dari kegiatan pendahuluan sampai kegiatan penutup berjalan dengan sangat baik. Peserta didik berpartisipasi aktif, diskusi interaktif guru dan peserta didik baik. Tumbuh keceriaan dan antusiasme dalam belajar. Membangun peserta didik untuk berpikir kritis dalam menyelesaikan permasalahan dan berhasil membimbing peserta didik untuk mengambil kesimpulan.

\section{Pembahasan}

Penerapan GBA dengan Model TLC pada pembelajaran Bahasa Inggris di SMPN 1 Panimbang telah memberikan hasil yang postif baik pada proses maupun hasil belajar. Dengan penerapan model ini, peserta didik secara bertahap mengalami proses pembelajaran secara bervariasi. Pada tahap BKOF, peserta didik diberikan latihan kosakata dan kalimat sebagai MODAL pengetahuan (concept building) untuk melakukan kegiatan selanjutnya. Latihan pada langkah ini melibatkan interaksi guru - kelas dan guru-peserta didik dan peserta didik- peserta didik. Modal pengetahuan tersebut diperkuat dengan MODEL pada tahap berikutnya, yaitu MOT. Kegiatan ini juga melibatkan komunikasi multi-arah (guru-kelas-peserta didik). Sebagaimana dikatakan sebelumnya bahwa kegiatan LATIHAN/PRAKTIK tidak bisa dilakukan tanpa modal pengetahuan yang memadai dan modal ini diperoleh melalui model (Sujana, dkk., 2019). Langkah ketiga dari model ini adalah JCOT, yaitu kegiatan berlatih bersama dengan berbekal modal pengetahuan dan model pada langkah 1 dan 2 di atas. Interaksi terjadi antar peserta didik dan sesekali dipandu oleh guru. Akumulasi dari ketiga langkah di atas adalah pada tahap ICOT, yaitu peserta didik melakukan kegiatan secara individu/mandiri. Langkah ini menjadi penting untuk memastikan bahwa kompetensi yang dibangun adalah kompetensi peserta didik secara individu, bukan kompetensi kelompok.

Dengan demikian, penerapan GBA memberikan kegiatan pembelajaran multi-arah dan berpusat pada peserta didik dengan porsi kegiatan didominasi oleh peserta didik. Pada masingmasing tahap pelibatan peserta didik dalam kegiatan pembelajaran sangat tinggi mulai dari kegiatan BKOF, MOT, JCOT, dan ICOT. Hal ini sejalan dengan harapan Direktorat GTK melalui kegiatan PKP ini yaitu merencanakan dan melaksanakan pemblajaran berpusat pada peserta didik (Ditjen GTK, 2019).

Selain itu, melalui penerapan GBA dengan TLC Mode, unsur 4C dalam Keterampilan Pembelajaran Abad 21 dan inovasi pembelajaran yang diharapkan dalam K-13 juga terpenuhi melalui sintaks pembelajaran TLC Model. Tahapan kegiatan BKOF mengandung unsur/aspek HOTS yaitu transfer knowledge. Tahap kegiatan MOT mengandung unsur creativity dan critical thinking. Begitu juga pada tahap JCOT dan ICOT, Keterampilan Pembelajaran Abad 21 yang tampak di sini adalah creative and critical thinking serta collaboration and communication. Hal senada juga disampaikan Sujana \& Puniawati (2020) yang menyimpulkan TLC Model mampu memenuhi tuntutan Keterampilan Pembelajaran Abad 21. Sejalan dengan hasil penelitian yang dilakukan Amalia dan Hartono (2015), sintaks TLC Model ini relevan dengan Pendekatan Saintifik yang disarankan dalam K-13. Melalui kegiatan BKOF peserta didik melakukan kegiatan mengamati dan menanya. Kegiatan MOT memberikan kesempatan peserta didik untuk mengamati, menanya, dan mengumpulkan data. Pada kegiatan ICT, peserta didik mengumpulkan informasi dan mengasosiasi data; sedangkan kegiatan MOT memberikan peluang peserta didik untuk melakukan komunikasi.

\section{KESIMPULAN}

Dari serangkaian analisis yang dilakukan, dapat disimpulkan sebagai berikut: (1) Dengan penerapan GBA peserta didik memiliki pengalaman secara bertahap dari pemberian modal, model, dan serangkaian latihan baik secara berkelompok maupun individu; (2) Penerapan GBA juga mampu mengakomodasi unsur 4C dalam Keterampilan Pembelajaran Abad 21. Creativity dan Critical thinking bisa dilihat pada tahap JCOT dan ICOT begitu pun dengan unsur Colaboration dan Communication. Pada tahap JCOT, peserta didik berkolaborasi atau bekerjasama ketika mengerjakan tugas/LK kelompok. Sedangkan unsur Communication 
tampak ketika peserta didik menampilkan hasil diskusinya dan juga di tahap ICOT mereka berlatih tampil mandiri untuk mempresentasikan hasil pekerjaannya; (3) Terjadi peningkatan tingkat ketuntasan belajar dari 39,72\% dengan rata-rata 60,28 sebelum pembelajaran menjadi 87,19\% dengan rata-rata 81,67 sesudah pembelajaran; dan (4) Kedua observer memberikan penilaian postif terhadap proses pembelajaran dengan penerapan GBA dengan Model TLC.

\section{DAFTAR PUSTAKA}

Abbaszadeh, Z. (2013). Genre-Based Approach and Second Language Syllabus Design. Procedia: Social and Behavioral Sciences, 84, 1879-1884.

Amalia, R. N. \& Hartono, R. (2015). The Integration of Genre-Based Approach into Scientific Approach in When English Rings a Bell to Teach Recount Text. Language Circle: Journal of Language and Literature, X/1, 85-92.

Brindley, G., (1989). "The Role of Need Analysis in Adult ESL Program Design", dalam R.K. Johnson (ed.). The Second Language Curriculum. Cambridge: CUP.

Cahyono, B.Y (2011). Teaching English by Using Various Text Types. Malang: Malang State University of Press.

Depdiknas (2004). Kurikulum 2004: Standar Kompetensi Mata Pelajaran Bahasa Inggris Kelas 4-6 SD dan MI. Jakarta: Departemen Pendidikan Nasional.

Derewianka, B. \& Jones, P. (2012). Teaching Language in Context. Victoria: Oxford University Press.

Ditjen GTK Kemendikbud (2019). Program Pengembangan Keprofesian Berkelanjutan (PKB) melalui Peningkatan Kompetensi Pembelajaran (PKP) Berbasis Zonasi. Jakarta: Ditjen GTK.

Douangmala, P. dan Widyantoro, A. (2016). The Use of Genre-Based Approach Instruction to Improve Students' Ability in Writing Short Essay. International Journal of Science and Research, 7(5), pp. 1141-1145.

Kementerian Pendidikan dan Kebudayaan. (2013). Paparan Pengembangan Kurikulum 2013. Jakarta: Kemendikbud

Kemendikbud. (2017). Model Silabus Mata Pelajaran SMP/MTs: Bahasa Inggris. Jakarta: Kementerian Pendidikan dan Kebudayaan.

Liang, E. L. (2015). Implementing Genre-Based Curriculum Cycle in Teaching Writing in Secondary School Settings. Studies in Literature and Language, 10 (1), 47-50.

Sujana, I M., Nuryanti, T. \& Narasintawati, L. S. (2010). Landasan Filosofi dan Teoritis Standar Isi Bahasa Inggris dalam KTSP dan Tantangan Kurikulum LPTK Bahasa Inggris, Jurnal Linguistik, Sastra, dan Budaya (Lisdaya), JPBS FKIP UNRAM, Vol. 6 No. 1, 2010

Sujana, I. M., Waluyo, U., Soepriyanti, H., \& Arifuddin. (2019). Penerapan DeconstructionConstruction Model dalam Menyusun PTK untuk Guru-Guru Bahasa Inggris Kota Mataram. Jurnal Pendidikan dan Pengabdian Masyarakat, 2 (2), 189-196.

Sujana, I M. \& Puniawati, I. A. W. (2020). Keterampilan Pembelajaran Abad 21 dalam Teaching Learning Cycles (TLC) Model (Refleksi Pembelajaran Bahasa Inggris dalam Program Penempatan Dosen di Sekolah (PDS)). Jurnal Ilmiah Profesi Pendidik (JIPP), Vol. 5 No. 1, 2020 